Cuando el totalitarismo marchitó todas las manifestaciones del pensamiento, el ingenio y la imaginación popular seguía produciendo chistes politicos. A veces la irreverencia de los súbditos era reprimida con salvaje dureza. La pena establecida para los chistes anti-Hitler era la muerte y hubo casos de ajusticiamiento por este delito. El humor antinazi era a la vez la expresión de una actitud de cierta resistencia, o al menos de disconformidad, $y$ una forma de terapia. También el chiste era un cómodo sustituto del pensamiento y más aún de la acción.

Muchas veces la persona que contaba un chiste y advertia a sus oyentes: "Esto son tres años de trabajos forzados", no lo hacia tanto llevado por su conciencia política como por el eterno afán que tiene el gracioso por despertar el interés de su auditorio.

De cualquier manera una gran cantidad de chistes políticos contenian poca hostilidad hacia el régimen. Esto es válido para un buen número de chistes sobre Hitler, en cambio los referidos a Göebbels eran casi siempre despectivos.

De todos los chistes sobre Hitler el que mejor refleja su personalidad es el que describe una salida de pesca de Hilter con Chamberlain y Mussolini. El prémier británico echa pacientemente el anzuelo, enciende la pipa y, al cabc, de dos horas, consigue una buena pieza. Musolini, por su parte, se tira de cabeza al agua y coge con las manos un gran lucio. Entonces Hitler ordena drenar el estanque. Al ver que los peces se retorcian indefensos en el fondo, Chamberlain pregunta: $Y$ ahora, ¿por qué no los coge usted?". Y Hitler responde: Primero tienen que suplicármelo.
A medida que la guerra avanzaba fue la propia situación militar del Reich la que se convirtió en tema de agrios comentarios.

¿Puede Alemania perder la guerra? No, desgraciadamente. Ahora que la tenemos, ya no nos libraremos de ella.

El tema del "Gran Hermano" era también otra fuente de humor. Un hombre a quien le duele una muela visita al dentista. Éste le pide que abra la boca. "Me guardaré muy mucho de abrir la boca delante de un perfecto desconocido". "Pero entonces, ¿cómo voy a sacarle la muela?" "Pues por detrás, naturalmente".

En invierno, dos silenciosos pasajeros de un tren hacen gestos apenas perceptibles con las manos, ocultas con la manta que cubre las rodillas. Son dos sordomudos que se cuentan chistes políticos.

El tema de la corrupción de los funcionarios dio lugar también a muchos chistes.

Dos funcionarios profesionales del partido dan un paseo por el bosque y uno de ellos se encuentra un billete de cincuenta marcos. Su compañero le pregunta: "qué va a hacer con él", "entregarlo a la Ayuda Invernal", contesta éste. A lo cual el otro replica: "Y por que no nos quedamos con él directamente".

Un viajero que pasa por un pueblo observa que unos hombres están retirando la veleta de la torre de la iglesia y les pregunta : "¿Van a poner una nueva?". "Oh, no. Vamos a sustituirla por un funcionario. Los funcionarios saben mejor que cualquier veleta de que lado sopla el viento y hacia donde va a cambiar."

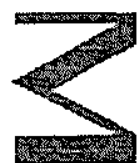

\title{
EL HUMOR EN LA ALEMANIA MAZI
}

julio Sánchez Hernández - Univ. de Sevilla 